\title{
EFL Teachers' Perceptions on Blackboard Applications
}

\author{
Mohammed Ali Mohsen ${ }^{1} \&$ Shafeeq C. $\mathrm{P}^{1}$ \\ ${ }^{1}$ Najran University, Saudi Arabia \\ Correspondence: Mohammed Ali Mohsen, Najran University, Saudi Arabia. E-mail: mmohsen1976@gmail.com
}

$\begin{array}{ll}\text { Received: August 31, } 2014 & \text { Accepted: October 1, } 2014 \quad \text { Online Published: October 23, } 2014 \\ \text { doi:10.5539/elt.v7n11p108 } & \text { URL: http://dx.doi.org/10.5539/elt.v7n11p108 }\end{array}$

\begin{abstract}
The widespread availability of technological infrastructure has enhanced the adoption of learning management systems (LMSs) in educational institutions. Blackboard is one of the most popular marketable LMSs adopted in higher education institutions. As some previous studies have viewed that positive perceptions played a vital role in adopting new technologies, this paper aims to investigate teachers' perceptions on blackboard applications in the context of teaching English as a foreign language (EFL). To gather data, 32 EFL university teachers from Saudi Arabia were surveyed and interviewed about their perceptions toward the use of the blackboard. The results from the data instruments reveal that EFL teachers have positive perceptions on Blackboard applications to English language teaching. Most teachers view Blackboard as a structured e-learning platform that helps improve the teacher-student relationship in a course and aids to make teaching English more successful. The study findings; however, revealed that the use of blackboard as a blending learning is still focusing on administrative issues rather than pedagogical significance for language learning. Recommendations and directions for future research are highlighted at the end of this article.
\end{abstract}

Keywords: teachers' perceptions, blackboard, CALL, language teaching, blended learning

\section{Introduction}

Blackboard, as a component of Learning Management System (LMS), has been adopted by many institutions due to its ubiquity, easiness, and accessibility. The rapid practices of online technology in everyday life, such as social network sites, motivate learners to get involved in online learning environment such as running discussion forum, writing assignments, and getting feedback from teachers and peers. On the other side, teachers' perception, whether positive or negative, to the use of Blackboard in teaching English as a foreign language (EFL) may play an important role in customizing students to be a part of online learning environment. Teachers' beliefs about the technology affect their decision to adopt it in classrooms. A survey conducted in 2007 on the use of technology by teachers in the US indicated that though teachers used technology in classrooms, their use of technology was limited to administrative purpose rather than pedagogical tasks (Ottenbreit-Leftwich, Glazewski, \& Ertmer, 2010). Research points out that technology has not been leveraged to its key resources to foster effective learning and teaching because the major task of using technology by most teachers is still to search for the material, notify students to write assignments, and use drill and practice (Ertmer \& Ottenbreit-Leftwich, 2010; Koc, 2013). Currently, the increasing demand is to shift the use of technology, particularly the Blackboard and Moodle, from a communication use to instructional tasks as to promote student-centered learning, which is meant to prioritize students' interest, abilities, and learning style. Considering the teachers role in making this shift, this paper aims to investigate teachers' perceptions on Blackboard applications in English as a foreign language (EFL) environment.

\section{Learning Management Systems (LMSs) in Education}

The widespread use of the Internet has enhanced the adoption of learning management systems (LMSs) in educational institutions. It is because of the availability of technological infrastructure, mainly of the Internet (Levy \& Stockwell, 2006; West, Waddoups, \& Graham, 2007). Web-based learning environment has created rich learning sources for all kinds of learners, interactive learning environments among students, teachers and course materials, and cross-cultural collaborative learning opportunities. This web-based learning system allows students and teachers interact with each other anywhere and anytime for their own needs (Cavus, 2007; Levy \& Stockwell, 2006).

The most popular LMS currently available to most institutions are Blackboard, WebCT, Moodle, LAMS, and 
SAKAI. Founded in 1997, Blackboard is a commercially licensed LMS, and is one of the most popular marketable LMSs adopted in higher education institutions (Chang, 2008; West, Waddoups, \& Graham, 2007). The tools in Blackboard have the potential to change the way teachers teach and learners learn (DeNeui \& Dodge, 2006). They offer a highly interactive medium of learning that can be customised to meet the individual needs of students (Levine \& Sun, 2003). These systems may influence the selection and development of online resources and affect traditional teaching practices, while also introducing a new layer of complexities into the management of teaching programs (Coates, 2007).

\section{Teachers' Perceptions on Technology Integration}

Though we live in the digital age, there is a slow change in instructional practices using technologies due to various levels of teacher's acceptance of e-learning tools. Still many teachers view technology as a supplementary teaching tool, and not as an essential component of successful teaching-learning process of our time. Some teachers even fear that online interaction between teacher and students replaces face-to-face interaction (Walker, 2004). Some others do not have the motivation or time to become expert users of online systems and limit their use of innovative pedagogies. The barriers to the use of innovations are understandable. However, teachers need to be convinced of the value of LMSs and other tools of online learning. It is becoming a reality that today's effective teaching requires effective technology use. However, research suggests that we have yet not achieved high levels of effective technology use even in technologically advanced countries (Kozma, 2003; Mueller, Wood, Willoughby, Ross, \& Specht, 2008; Smeets, 2005; Tondeur, van Braak, \& Valcke, 2007). Further, technologies used in many parts of the world are not capable of facilitating student learning, as they simply support lecture-based instruction and do not enhance student-centred pedagogy (Cuban, Kirkpatrick, \& Peck; 2001; Law-less \& Pellegrino, 2007; Zemelman, Daniels, \& Hyde, 2005). It is high time that we focus further on thinking about more creative ways to use the innovation to improve teaching and learning (West, Waddoups, \& Graham, 2007).

The above realities show that teachers' perceptions on technology integration play a vital role in successful integration of technology to language learning and teaching. As Kagan (1992) noted, teachers' beliefs appear to lie at the heart of teaching and tend to be associated with a congruent style of teaching. Hence, changes to teaching style with technology necessitate changes to teachers' beliefs. Further, teaching beliefs have an impact on institutional practice and policy (Kane, Sandretto, \& Heath, 2002). Research based on teacher-belief has concluded that the interrelationships between beliefs and actions are what support and inspire practice (e.g., Albion, 1999; Albion \& Ertmer, 2002; Ertmer, Gopalakrishnan, \& Rosse, 2001). Research has also indicated that teachers must see a direct link between the technology and the curriculum for which they are responsible (Ertmer, 2005), and real technology integration happens when it is effectively applied to a curriculum and to the students' learning. The models of incorporating technology into the curriculum and into student learning suggest that the teacher is an integral part of the integration of technology (Dockstader, 1999). Since technology has become a key component in our lives, understanding its implications, utilising its potential and becoming comfortable with its effect are necessary skills in today's workplace. New technologies do not necessarily cause a change in pedagogical practice; instead, it may reinforce existing pedagogical foundation and outlook (Zurita \& Ryberg, 2005). However, successful use of computer technology requires an instructional change to constructivist teaching (Strommen \& Lincoln, 1992; Jonassen, Peck, \& Wilson, 1999) that is student-centred learning (Pedersen \& Liu, 2003; Sandholtz, Ringstaff, \& Dwyer, 1997).

\section{Teachers' Perceptions on Blended Learning in EFL Context}

The present study provides a quantitative examination in order to understand how EFL teachers' perceive the process of adoption of the Blackboard applications. With the advent of Computer-assisted Language Learning (CALL), it has been established that computer software can be used a medium for communication and negotiation of meaning in the target language. Currently, computers and the Internet together have been described to be the tools with the most potential for the field of language learning (Warschauer \& Healey, 1998). Computers represent a great potential for the facilitation of language input because of their ability to integrate multimedia material such as videos, images, and text simultaneously into one single screen. However, language teachers still have not determined which technologies are chosen for their use and technology integration remains an issue. Therefore, the need for teacher education and learner training in the area is increasingly becoming regarded as essential (Levy, 2009). The future of CALL is closely tied to the future of language teacher education because language teachers are the pivotal players. Teachers need to select the tools to support their teaching and determine what CALL applications language learners should be exposed to and how learners can use them. However, many language teachers are leaving their certification and degree programs with little or nothing in the way of formal training in the use of technology in language teaching (Hubbard, 2008). To change 
pedagogical practice through technology, a teacher has to arrive at the highest level of digital competence with tools, and be able to think creatively with them. It necessitates the teachers to have a holistic view of the principles and philosophies behind the designs of an e-learning system in order for them to better apply appropriate pedagogies and learning theories to their teaching (Bennett \& Marsh, 2002).

There has been a steady increase of online language learning over the last decade with the growth of the Internet and the proliferation of computers at home and in many educational institutions (Hubbard \& Levy, 2006). This context of language learning has prompted the need for new teaching approaches and teaching skills that are different from the traditional methods (Hampel \& Stickler, 2005). In addition, teaching language online requires skills that are different from those used to teach language in face-to-face classrooms. Language teaching and learning context of the present day prefers blended learning that mixes different learning environments. It assumes the continued use of face-to-face teaching as a basic building block of the learning experience, enriched and enhanced by the integration of the Internet and other teaching and learning technologies into studies undertaken both in and out of the classroom. This integration should take place with the mediation and support of the teacher, and should reflect and work toward the learning aims and needs of all learners. LMSs used in educational institutions offer a platform for blended learning. Thus, constructivist and communicative approaches, along with $21^{\text {st }}$ century integrative CALL, open a wide range of resources for foreign language learning.

As many institutions adopted hybrid approaches to foreign language learning, which blends face-to-face instruction with online activities and computer-based practice (Comas-Quinn, 2011; Compton, 2009), the questions and concerns regarding instructors' preparation have been raised by some researchers (Hauck \& Stickler, 2006). Research endorses the importance of instructors' technological and pedagogical skills to successfully implement web-based teaching-learning activities (Comas-Quinn, 2011; Compton, 2009; Hauck \& Stickler, 2006). This prompts the necessity for training that can provide opportunities to develop an understanding of the impact of a hybrid approach with reference to the instructor's roles and engagement in the learning process (Comas-Quinn, 2011). It is also important to know how teaching practices might be influenced in a blended learning context that might affect perceptions and views of one's roles in the foreign language classroom (Blake, 2009). Drewelow (2013) is of the view that participating in online discussions, providing feedback on assignments, and communicating with students allow the instructor to be a co-participant in the learning process. This is where instructors' understanding of how incorporating technology into teaching effects their roles in a hybrid course. These factors necessitate the present day EFL teachers to possess right perceptions on different applications of CALL for effective venture in future.

The purpose of the present study is to investigate the teachers' perceptions on Blackboard applications in EFL. The previous studies on teachers' perceptions in EFL show that exploring the relationship between teachers' and students' beliefs about teaching and learning help teachers develop their methodology and style of teaching to fit into a particular situation (Ahmad \& Aziz, 2009). Lack of experience and knowledge regarding the various roles an instructor should assume in a blended learning approach may result in instructors' weaker engagements in the learning community and affect their teaching practices (De Laat et al., 2006). Therefore, the instructors, who will use an online component for teaching, need to acquire a pedagogical understanding of the affordances of the online medium during their training, to ensure their readiness to teach online (Comas-Quinn, 2011). Comas-Quinn (2011) concludes that the better the instructors understand what constitutes their roles and responsibilities in the hybrid environment, the more the learning process will be facilitated. The recent study by Drewelow (2013) points to the need for further exploration of instructors' beliefs and understandings in relation to roles and teaching practices in the hybrid foreign language classroom because of their implications for training. Further, the research calls for a continuing reflective practice as well as collaborative practice (Drewelow, 2013). Such suggestions justify the necessity of studies on teachers' perceptions on LMS applications in an EFL context that may lead to effective ventures in the new generation language teaching and learning. This study tries to answer the following question:

"How do teachers perceive the Blackboard applications in EFL environment?"

\section{Methodology}

\subsection{Participants}

32 EFL teachers in two universities in Saudi Arabia were selected as a sample of this study. They are teaching English in different university levels. The participants' age varies between 27-45, with the average age being 36.65. All of them are non-native speakers of English; 17 Indians, 11 Arabs, and 4 Africans. Their experience of teaching English varies between 3-20 years. The participants have been using the Blackboard for at least 2 years and some of them had been trained in Blackboard use by their institutions. The total population of English instructors was 122 and only 52 were utilizing the Blackboard in their teaching. The researchers circulated the 
survey to all the participants via emails and to some by hands. As the number of EFL instructors was limited, we selected all the population as a sample of our study. Table 1 depicts the demographic information about the participants.

Table 1. Demographic data of the participants

\begin{tabular}{lllllll}
\hline & Period & No. & Period & No. & Period & No. \\
\hline Age group (Years) & $20-30$ & 2 & $30-40$ & 20 & $40-50$ & 10 \\
Experience (Years) & Less than five years & 3 & $5-10$ & 15 & $10-20$ & 9 \\
\hline
\end{tabular}

\subsection{Assessment Methods}

Two assessment methods were used to gather data from the participants: (1) a survey and (b) an interview. The survey was constructed by the researchers, containing two unfold sections: demographic information about the participants and their perceptions towards the use of the Blackboard (see appendix A). The aim of the questionnaire was to measure how teachers perceived the use of Blackboard in language teaching settings. The statements of the questionnaire contained either positive or negative attitudes towards implementing the Blackboard in EFL environment. Using a 5-Point Likert-scale, the questionnaire scaled from 1-5 (ranging from 1 which means "strongly disagree" to 5 which means "strongly agree". On the other hand, the scale for the negative statements was 1 "strongly agree" and 5 "strongly disagree". To ensure the validity of the survey, it was first piloted by 10 EFL instructors; their feedback was useful for modifying some items. The survey was also given to two professors of applied linguistics to examine its validity. Some items were modified as per the panel's suggestions so as to achieve the content validity. The survey, containing 25 statements, was distributed via email as well as by hand to all the study participants. The percentage of returned questionnaires is sufficient at $61 \%$ from both the universities. A reliability analysis was calculated for the survey. The reliability results were (Cronbach's alpha) 0.884 for all the survey items, indicating the items were very high and acceptable.

15 EFL teachers were interviewed to support the data obtained from the survey and to further give the respondent an opportunity to express his perceptions orally. The interview questions were semi-structured and focused on EFL teachers' perceptions of Blackboard applications. During the interviews, participants described their views regarding the benefits of Blackboard from the perspective of pedagogy of teaching English, its contributions in improving students' language competencies, and practical barriers in effective Blackboard integration in EFL.

\section{Results and Discussion}

\subsection{Analysis of the Survey}

To answer the research question, "How do teachers perceive the use of blackboard in EFL environment?" descriptive statistics have been calculated to indicate the means, standard deviation, and frequency of the participants' responses to the survey. Table 2 reports the descriptive statistics for the positive points indicated by the survey. The means, standard deviation, and frequency for the negative elements provided by the survey are summarized in Table 3.

Table 2. Descriptive statistics of the survey's positive statements

\begin{tabular}{|c|c|c|c|c|c|c|c|c|}
\hline & \multirow{2}{*}{ Statement } & \multicolumn{5}{|c|}{ Percent \% } & \multirow{2}{*}{$M$} & \multirow{2}{*}{$S D$} \\
\hline & & SA & A & $\mathrm{N}$ & $\mathrm{D}$ & SD & & \\
\hline 1 & $\begin{array}{l}\text { I believe that teaching English via } \mathrm{BB} \text { will increase } \\
\text { students' motivation to learn a language }\end{array}$ & 15.6 & 56.3 & 3.1 & 25 & 0 & 4.84 & 0.7 \\
\hline 2 & I like BB because it is a structured e-learning platform & 18.8 & 62.5 & 18.8 & 0 & 0 & 4.12 & 1.1 \\
\hline 3 & $\begin{array}{l}\text { BB helps improve the teacher-student relationship in a } \\
\text { course }\end{array}$ & 12.5 & 78.1 & 9.4 & 0 & 0 & 4.03 & 0.5 \\
\hline 4 & BB helps make teaching English more successful & 21.9 & 59.4 & 15.6 & 3.1 & 0 & 4.00 & 0.7 \\
\hline 5 & BB facilitates the way I teach & 15.6 & 53.1 & 31.3 & 0 & 0 & 3.84 & 0.7 \\
\hline 6 & $\begin{array}{l}\text { I believe students' use of bb would reinforce self- study } \\
\text { learning }\end{array}$ & 25 & 53.1 & 6.3 & 12.5 & 3.1 & 3.84 & 1.1 \\
\hline 7 & I think BB has enough functionality for managing my & 9.4 & 71.9 & 9.4 & 9.4 & 0 & 3.81 & 0.7 \\
\hline
\end{tabular}




\begin{tabular}{|c|c|c|c|c|c|c|c|c|}
\hline & course documents & & & & & & & \\
\hline 8 & $\mathrm{BB}$ is user friendly & 12.5 & 71.9 & 9.4 & 3.1 & 3.1 & 3.8 & 0.8 \\
\hline 9 & $\begin{array}{l}\text { BB supports the pedagogical principles that I want to } \\
\text { use for teaching English with technology }\end{array}$ & 6.3 & 68.8 & 21.9 & 3.1 & 0 & 3.78 & 0.6 \\
\hline 10 & $\begin{array}{l}\text { I think students get more exposure to language learning } \\
\text { via online activities available in BB }\end{array}$ & 18.75 & 40.6 & 37.5 & 3.1 & 0 & 3.75 & 0.8 \\
\hline 11 & The use of BB tools focus on students-centered learning & 12.5 & 4.6 & 18.8 & 28.1 & 0 & 3.73 & 1.0 \\
\hline 12 & $\begin{array}{l}\mathrm{BB} \text { is a good platform for students to learn a foreign } \\
\text { language }\end{array}$ & 12.5 & 62.5 & 9.4 & 15.6 & 0 & 3.71 & 0.9 \\
\hline 13 & $\begin{array}{l}\text { I think using BB will promote students' use of English } \\
\text { to communicate with peers and instructors }\end{array}$ & 12.5 & 53.1 & 21.9 & 12.5 & & 3.65 & 0.9 \\
\hline 14 & $\begin{array}{l}\text { My perception of BB changed as I have gained more } \\
\text { online teaching experience }\end{array}$ & 9.4 & 50 & 34.4 & 6.3 & 0 & 3.62 & 0.8 \\
\hline 15 & $\begin{array}{l}\text { BB helps students improve their Language } \\
\text { competencies }\end{array}$ & 3.12 & 56.3 & 40.6 & 0 & 0 & 3.62 & 0.6 \\
\hline 16 & $\begin{array}{l}\text { Using BB would augment working collaboratively in } \\
\text { peers as well as in groups }\end{array}$ & 9.4 & 46.9 & 34.4 & 6.3 & 3.1 & 3.53 & 0.9 \\
\hline 17 & $\begin{array}{l}\text { I believe learning English via BB would make student } \\
\text { feel autonomous }\end{array}$ & 6.3 & 50 & 34.4 & 3.1 & 6.3 & 3.46 & 0.9 \\
\hline 18 & $\begin{array}{l}\text { The rate of students' interaction with materials provided } \\
\text { in BB is encouraging }\end{array}$ & 12.5 & 34.4 & 34.4 & 12.5 & 6.3 & 3.43 & 1.1 \\
\hline 19 & $\begin{array}{l}\text { The interface of BB would draw students' attention to } \\
\text { learn English efficiently }\end{array}$ & 3.1 & 37.5 & 50 & 9.4 & 0 & 3.34 & 0.7 \\
\hline
\end{tabular}

The results from the descriptive statistics reveal that EFL teachers showed positive attitude towards the application of Blackboard to English language teaching. To interpret the level of means, the authors applied Siti Rahaya and Salbiah's (1996) model of explaining means. It is summarized in Table 4.

Examining the results from Table 2, the teachers show significant perceptions to the positive statements they surveyed. The results from the descriptive statistics reveal that EFL teachers showed positive attitude towards the application of the blackboard to English language teaching. Almost all the items obtained high/very high scale except the item 19 which is related to technical issues (i.e., The interface of Blackboard would draw students' attention to learn English efficiently). One item got 4.84 which is rated as very high, 17 statements obtained between 3.43-4.12, which are rated as high, and one item rated as moderate, obtaining 3.34. The total mean of the 19 statements is 3.78 , indicating that the overall mean of the positive statements is high.

Table 3. Descriptive statistics of the survey's negative statements

\begin{tabular}{|c|c|c|c|c|c|c|c|c|c|}
\hline & \multirow{2}{*}{ Statement } & \multicolumn{5}{|c|}{ Percent } & \multirow{2}{*}{$\begin{array}{l}\text { SA and } \\
\text { A } \%\end{array}$} & \multirow{2}{*}{ M } & \multirow{2}{*}{ SD } \\
\hline & & SA & $\mathrm{A}$ & $\mathrm{N}$ & $\mathrm{D}$ & SD & & & \\
\hline 20 & $\begin{array}{l}\text { I don't think that learning via BB is efficient } \\
\text { because some teachers may find it difficult to } \\
\text { handle }\end{array}$ & 0 & 25 & 34.4 & 31.3 & 3 & 25 & 2.75 & 1.0 \\
\hline 21 & BB lacks customization & 3.1 & 25.5 & 43.8 & 25.0 & 3.1 & 28.12 & 3.00 & 0.9 \\
\hline 22 & $\begin{array}{l}\text { I do not think using BB will improve overall } \\
\text { student performance in EFL }\end{array}$ & 3.1 & 28.1 & 15.6 & 43.8 & 9.4 & 31.25 & 2.71 & 1.1 \\
\hline 23 & $\begin{array}{l}\text { I would not recommend using BB because it } \\
\text { has several technical problems }\end{array}$ & 9.37 & 21.5 & 15.6 & 4.6 & 12.5 & 31.25 & 2.75 & 1.2 \\
\hline 24 & I find it too time consuming to use $\mathrm{BB}$ & 12.5 & 21.9 & 25.0 & 34.4 & 6.3 & 34.37 & 3.00 & 1.1 \\
\hline 25 & $\begin{array}{l}\text { The technical aspects of } \mathrm{BB} \text { discourage me } \\
\text { from using it more frequently }\end{array}$ & 3.12 & 37.5 & 12.5 & 4.6 & 6.3 & 40.62 & 2.9 & 1.1 \\
\hline
\end{tabular}

Concerning the negative statements, outlined in Table 3, the descriptive statistics show fewer frequencies than the positive points shown in Table 2 . The means of the negative statements are less than those in the positive statements. In addition, teachers' responses were not significant. As indicated in Table 3, the mean varies 
between the scale 'moderate' and 'low'. None of the negative statements scaled high or very high, all of them scaled as moderate. The overall mean for the negative statements is 2.8 , demonstrating that the overall mean of the negative statements is moderate.

Table 4. Score category breakdown adopted from Siti Rahaya and Salbiah (1996)

\begin{tabular}{ll}
\hline Means & Corresponding level \\
\hline $1.0-1.80$ & Very low \\
$1.81-2.60$ & Low \\
$2.61-3.40$ & Moderate \\
$3.41-4.20$ & High \\
$4.21-5.0$ & Very high \\
\hline
\end{tabular}

\subsection{Analysis of the Interview}

The interview data were analyzed based on the constant comparative method (Glaser \& Strauss, 1967; Strauss \& Corbin, 1990), and the coding process followed the analysis of the grounded theory (Strauss \& Corbin, 1990). Any words or sentences relating to the teachers' perceptions and expectations of the role of Blackboard and its contribution to language learning were coded, conceptualized, and categorized using the constant comparative approach until the categories were saturated.

\section{Question 1. What are the benefits of Blackboard from the perspective of pedagogy of teaching English?}

Three categories emerged from the data regarding the benefits of Blackboard from the perspective of pedagogy of teaching English: innovative methods in Blackboard, interactive lessons in Blackboard, and motivation in Blackboard use.

Innovative methods in Blackboard. During the interviews, the teachers frequently mentioned that innovative methods of Blackboard applications help to make teaching of English lively. Use of IT skills for language learning help to get immediate feedback from instructors. In addition, multimedia aids and other materials (audio/video/text) make possibility of rich experience. Online drills and quizzes help to check the progress of linguistic acquisition. Some teachers also said that linguistic skills were encouraged with technology. One respondent felt that it was a good platform to practice writing with the help of teacher's feedback.

Interactive lessons in Blackboard. Almost all respondents were of the view that Blackboard supported interactive lessons by allowing the students to interact with teachers anywhere at any time. One of the respondents kept the view that online assignments help to build teacher-student rapport using computer-mediated communication.

Motivation in Blackboard use. Commonly, the teachers assumed that Blackboard's motivational feature was high. Its interactive features like chatting, discussion forums etc. allowed considerable amount of peer learning. One of the teachers opined that as there were no time-constraints to access the materials on Blackboard, it helped the students to cover up the missed classes. Some others viewed that fear-free environment as compared to the real classrooms was another motivational factor for students to involve themselves. As one of them noted, providing autonomy is the key factor that makes Blackboard justifiable in language teaching-learning scenario. "No more monotony of traditional system" was the comment made by another teacher.

\section{Question 2. How can Blackboard help students improve their language competencies?}

The responses to this question were divided into two main categories: (1) pragmatic practice in Blackboard and (2) exposure to language in Blackboard.

Pragmatic practice in Blackboard. Most teachers assumed that Blackboard was a platform for Pragmatic practice. It could help to improve linguistic skills: listening, speaking, reading, and writing. Group discussions enabled them to construct their own sentences. Vocabulary and grammar exercises helped to understand grammatical structures and language use.

Exposure to language in Blackboard. This point was endorsed by many teachers. They assumed that blended learning using Blackboard allowed more time to access information. It was also assumed that IT use led to language exposure. Many teachers believed that group conferencing and chatting were beneficial to develop communicative English. Putting interesting materials maximized student-teachers interaction, as one observed.

Question 3. What are the barriers/technical problems of Blackboard integration in your EFL context? 
Though most of the teachers have positive perceptions on Blackboard, they point out some barriers or technical problems that hinder effective integration of Blackboard in the concerned EFL context. These barriers can be categorized into three: teachers' incompetency in IT, students' incompetency IT, and Technical Problems.

Teachers' incompetency in IT. As one of the teachers responded, some teachers who were new to Blackboard might find it difficult to shift their roles from a traditional face to face approach to a blended learning situation. This difficulty is partly because of their incompetency in handling technology. As many teachers' noted, non-availability of technical staff deepened this difficulty situation.

Students' incompetency IT. Low student response to the assignments on Blackboard was a matter of concern, as some teachers said. The reasons vary. One of the teachers said: "Some of the students are not well aware of using this technology"

This happens because the Internet facility is not available to all students, especially those who come from rural settings. Another factor is the language barrier for beginners as Blackboard applications are in English and students may find it difficult to handle in the absence of adequate training. Interestingly, one of the teachers was of the view that students would be distracted towards other online activities such as social networking and YouTube.

Technical Problems. Another barrier mentioned by some of the teachers was technology itself. Some teachers felt that it was not always reliable. Complex nature of some applications might discourage their use, as one of them observed. Too much emphasis on Blackboard applications discouraged real classroom attendance, one of them complained. Though most teachers support the benefits of online learning, there are some observations like this:

"Well, it's not valid to apply on all of the language skills. Learning a language always needs more real normal interactions".

\section{Conclusion}

The study reveals that EFL teachers have positive perceptions towards the application of the Blackboard to English language teaching. It is interesting to note that the item, which states teaching English via Blackboard, will increase students' motivation to learn a language got the highest mean (4.84). This shows that most teachers have positive pedagogical perceptions regarding the integration of technology in language teaching. Such positive perceptions play a vital role in adopting a new technology as mentioned by previous studies (Albion \& Ertmer, 2002; Ertmer, Gopalakrishnan, \& Rosse, 2001). Most teachers view Blackboard as a structured e-learning platform that helps improve the teacher-student relationship in a course and aids to make teaching English more successful. As some previous findings show, instructors' technological and pedagogical understandings help to successfully implement web-based teaching-learning activities (Comas-Quinn, 2011; Hauck \& Stickler, 2006).

As most of the participants mentioned that they could easily operate the tools, it determines that Blackboard is easy to use. Though some teachers have talked about their reservations on the practical aspects of using Blackboard, most teachers have not endorsed the ideas that some teachers may find it difficult to handle or Blackboard lacks customization. In addition, it is a good sign that most teachers have endorsed the view that Blackboard supports interactive lessons by allowing the students to interact with teachers anywhere at any time. Hence, the research question proposed for this research "How do the EFL teachers perceive the process of adoption of the Blackboard applications?" could be concluded that the teachers find it a beneficial tool that enhances student learning.

\section{Suggestions for Future Research}

In this study, EFL teachers' perceptions on Blackboard applications have been analysed in general. It would be interesting to study teachers' perceptions using other variables like age, gender, experience etc. In addition, as this research is focused on a limited geographical area, it is required to apply similar research for other EFL or ESL contexts, and compare the results for match and mismatch of teachers' opinions on Blackboard usage. Also, it is strongly suggested, for similar future studies, to obtain a larger survey sample. A wide-scale survey sent to a more diverse sample and a larger case study could help to strengthen the results.

The LMS used in this study is Blackboard, and it is recommended to conduct a similar study using an LMS with a different pedagogical perspective, such as Moodle, to see how the results differ from the current study. The study specifically investigated EFL teachers' perceptions toward technology and the data was gathered from a survey. However, the researchers did not make observations of actual practices, and it could be useful to apply this technique in further research to have a better interpretation of what the teachers report about the actual practices. It could be very interesting to compare the perceptions and actual limitations regarding LMS in 
education.

Lastly, the findings of this study show that EFL teachers possess positive attitudes regarding blended learning. It is also significant to know the perceptions of administrators who make decisions regarding faculty development. Hence, it is important to include decision makers in further research.

\section{Acknowledgements}

This project has been funded by the Deanship of Scientific Research, Najran University, grant No. NU/SHED/13/39.

\section{References}

Ahmad, F., \& Aziz, J. (2009). Students' perception of the teachers' teaching of literature communicating and understanding through the eyes of audience. European Journal of Social Sciences, 7(3), 17-26.

Albion, P. (1999). Self-efficacy beliefs as an indicator of teachers' preparedness for teaching with technology. In Proceedings of the 10th International Conference of the Society for Information Technology \& Teacher Education (SITE 1999) (pp. 1602-1608). Association for the Advancement of Computing in Education (AACE).

Albion, P. R., \& Ertmer, P. A. (2002). Beyond the foundations: The role of vision and belief in teachers' preparation for integration of technology. TechTrends, 46(5), 34-38.

Blake, R. J. (2009). The use of technology for second language distance learning. Modern Language Journal, 93(Focus issue), 822-835.

Cavus, N. (2007). Assessing the success rate of students using a leaning management system together with a collaborative tool in Web-Base teaching of programming languages. Journal of Educational Computing Research, 36(3), 301-321.

Chang, C. (2008). Faculty perceptions and utilization of a learning management system in higher education (Unpublished doctoral dissertation). Ohio University, 2008.

Coates, H. (2007). A model of online and general campus-based student engagement. Assessment \& Evaluation in Higher Education, 32(2), 121-141.

Comas-Quinn, A. (2011). Learning to teach online or learning to become an online teacher: An exploration of teachers' experiences in a blended learning course. ReCALL Journal, 23(3), 218-232.

Compton, L. K. L. (2009). Preparing language teachers to teach language online: A look at skills, roles, and responsibilities. Computer Assisted Language Learning, 22(1), 73-99.

Corbin, J. M., \& Strauss, A. (1990). Grounded theory research: Procedures, canons, and evaluative criteria. Qualitative sociology, 13(1), 3-21.

Cuban, L., Kirkpatrick, H., \& Peck, C. (2001). High access and low use of technologies in high school classrooms: Explaining an apparent paradox. American Educational Research Journal, 38(4), 813-834.

De Laat, M., Lally, V., Lipponen, L., \& Simons, R.-J. (2006). Online teaching in networked learning communities: A multi-method approach to studying the role of the teacher. Instructional Science, 35(3), 257-286.

DeNeui, D. L., \& Dodge, T. L. (2006). Asynchronous Learning Networks and Student Outcomes: The Utility of Online Learning Components in Hybrid Courses. Journal of Instructional Psychology, 33(4), 256-259.

Dockstader, J. (1999). Teachers of the 21st century know the what, why, and how of technology integration. THE journal, 26(6), 73-74.

Drewelow, I. (2013). Exploring graduate teaching assistants' perspectives on their roles in a foreign language hybrid course. System, 41(4), 1006-1022.

Ertmer, P. A. (2005). Teacher pedagogical beliefs: The final frontier in our quest for technology integration? Educational technology research and development, 53(4), 25-39.

Ertmer, P. A., Gopalakrishnan, S., \& Ross, E. M. (2001). Technology-Using Teachers. Journal of Research on Computing in Education, 33(5), 1-26.

Ertmer, P. A., \& Ottenbreit-Leftwich, A. T. (2010). Teacher technology change: how knowledge, confidence, beliefs, and culture intersect. Journal of research on Technology in Education, 42(3), 255-284.

Glaser, B., \& Strauss, A. (1999). The Discovery of Grounded Theory: Strategies for Qualitative. Research. London: Wiedenfeld and Nicholson. 
Hauck, M., \& Stickler, U. (2006). What does it take to teach online? CALICO Journal, 23(3), 463-475.

Hampel, R., \& Stickler, U. (2005). New skills for new classrooms: Training tutors to teach languages online. Computer Assisted Language Learning, 18(4), 311-326.

Hubbard, P., \& Levy, M. (2006b). The scope of CALL education. In P. Hubbard, \& M. Levy (Eds.), Teacher education in CALL (pp. 3-21). Amsterdam: John Benjamins.

Jonassen, D. H., Peck, K., \& Wilson, B. G. (1999). Learning with technology: A constructivist approach. Merrill/ Prentice-Hall: Upper Saddle River, NJ.

Kagan, D. M. (1992). Implications of research on teacher belief. Educational Psychologist, 27(1), 65-90.

Kane, R., Sandretto, S., \& Heath, C. (2002). Telling half the story: A critical review of research on the teaching beliefs and practices of university academics. Review of educational research, 72(2), 177-228.

Koc, M. (2013). Student teachers' conceptions of technology: A metaphor analysis. Computers \& Education, 68 , $1-8$.

Kozma, R. B. (2003). Technology and classroom practices: An international study. Journal of Research on Technology in Education, 36, 1-14.

Lawless, K. A., \& Pellegrino, J. W. (2007). Professional development in integrating technology into teaching and learning: Knowns, unknowns, and ways to pursue better questions and answers. Review of Educational Research, 77, 575-614.

Levine, A., \& Sun, J. C. (2003). Distributed education: Summary of a six-part series. Washington, DC: American Council on Education.

Levy, M., \& Stockwell, G. (2006). CALL Dimensions: Options and issues in computer assisted language learning. Mahwah, NJ: Lawrence Erlbaum.

Mueller, J., Wood, E., Willoughby, T., Ross, C., \& Specht, J. (2008). Identifying discriminating variables between teachers who fully integrate computers and teachers with limited integration. Computers \& Education, 51(4), 1523-1537.

Ottenbreit-Leftwich, A. T., Glazewski, K. D., Newby, T. J., \& Ertmer, P. A. (2010). Teacher value beliefs associated with using technology: Addressing professional and student needs. Computers \& Education, 55(3), 1321-1335.

Pedersen, S., \& Liu, M. (2003). Teachers' beliefs about issues in the implementation of a student-centered learning environment. Educational Technology Research and Development, 51(2), 57-76.

Sandholtz, J. H., Ringstaff, C., \& Dwyer, D. C. (1997). Teaching with technology: Creating student-centered classrooms (Vol. 211). New York: Teachers College Press.

Smeets, E. (2005). Does ICT contribute to powerful learning environments in primary education? Computers \& Education, 44(3), 343-355.

Strommen, E. F., \& Lincoln, B. (1992). Constructivism, technology, and the future of classroom learning. Education and Urban Society, 24(4), 466-476.

Tondeur, J., Van Braak, J., \& Valcke, M. (2007). Curricula and the use of ICT in education: Two worlds apart? British Journal of Educational Technology, 38(6), 962-976.

Walker, G. (2004). Faculty intentions to use web-enhanced instructional components. Retrieved February 22, 2014, from http://home.hawaii.rr.com/gregaloha/Walker\%20Greg\%20 Dissertation.pdf

Warschauer, M. (1997). Computer-mediated collaborative learning: Theory and practice. The Modern Language Journal, 81(4), 470-481.

West, R. E., Waddoups, G., \& Graham, C. R. (2007). Understanding the experiences of instructors as they adopt a course management system. Educational Technology Research and Development, 55(1), 1-26.

Zemelman, S., Daniels, H., \& Hyde, A. (2005). Best practice: Today's standards for teaching and learning in America's schools. Portsmouth, NH: Heinemann.

Zurita, L., \& Ryberg, T. (2005). Towards a collaborative approach of introducing e-learning in higher education institutions. How do university teachers conceive and react to transitions to e-learning? IFIP World Conference on Computers in Education, WCCE. Cape Town, South Africa 


\section{Appendix A}

Questionnaire: Technological Perceptions of EFL Teachers on Blackboard Applications

\section{Section A: Background Information}

1. Name (optional):

2. Email Address:

3. Please choose your job/position:
a. Language Instructor b. Lecturer
c. Assistant Professor
d. Associate Professor

4. Please select your age group:
a. $20-30$
b. $30-40$
c. $40-50$
d. 50 and above

5. Teaching experience (in years):
a. Less than 5 years
b. 5 to 10 years
c. 10 to 20 years
d. More than 20 years

6. Have you ever attended a formal training course on Blackboard Applications?
a. Yes
b. No

7. Have you received training in e-learning at your college?
a. Yes
b. No

8. How would it affect your usage of Blackboard if further training is provided?

Choose one of the following options.
a. Not at all
b. Small Increase
c. Significant Increase

9. What percentage (\%) of your course materials are on Blackboard?
a. $0-20$
b. $20-40$
c. $40-60$
d. $60-80$
e. $80-100$

Section B: Please read each statement and then tick one that best describes how you feel.

1. Blackboard is user friendly.

Strongly Agree Agree Neutral Disagree $\quad$ Strongly Disagree

2. Blackboard helps improve the teacher-student relationship in a course.

Strongly Agree Agree Neutral Disagree $\quad$ Strongly Disagree

3. Blackboard helps make teaching English more successful.

Strongly Agree Agree Neutral Disagree $\quad$ Strongly Disagree

4. Blackboard facilitates the way I teach.

Strongly Agree Agree Neutral Disagree $\quad$ Strongly Disagree

5. Blackboard supports the pedagogical principles that I want to use for teaching English with technology.

Strongly Agree Agree Neutral Disagree $\quad$ Strongly Disagree

6. I find it too time consuming to use Blackboard.

$\begin{array}{llll}\text { Strongly Agree } & \text { Agree } & \text { Neutral } & \text { Disagree }\end{array}$

7. Blackboard lacks customization.

Strongly Agree Agree Neutral Disagree $\quad$ Strongly Disagree

8. I do not think using Blackboard will improve overall student performance in EFL.

Strongly Agree Agree Neutral Disagree $\quad$ Strongly Disagree

9. The technical aspects of Blackboard discourage me from using it more frequently.

Strongly Agree Agree Neutral Disagree $\quad$ Strongly Disagree

10. I like Blackboard because it is a structured e-learning platform.

$\begin{array}{llll}\text { Strongly Agree } & \text { Agree } & \text { Neutral Disagree } & \text { Strongly Disagree }\end{array}$

11. I think Blackboard has enough functionality for managing my course documents. 
Strongly Agree Agree Neutral Disagree $\quad$ Strongly Disagree

12. My perception of Blackboard changed as I have gained more online teaching experience.

Strongly Agree Agree Neutral Disagree $\quad$ Strongly Disagree

13. Blackboard helps students improve their language competencies.

Strongly Agree Agree Neutral Disagree $\quad$ Strongly Disagree

14. The rate of students' interaction with materials provided on Blackboard is encouraging.

Strongly Agree Agree Neutral Disagree $\quad$ Strongly Disagree

15. Blackboard is a good platform for students to learn a foreign language.

Strongly Agree Agree Neutral Disagree $\quad$ Strongly Disagree

16. I believe that teaching English via Blackboard will increase students' motivation to learn a language.

Strongly Agree Agree Neutral Disagree $\quad$ Strongly Disagree

17. I think students get more exposure to language learning via online activities available on Blackboard.
Strongly Agree
Agree
Neutral
Disagree
Strongly Disagree

18. The use of Blackboard tools focuses on students-centered learning.
Strongly Agree
Agree
Neutral
Disagree
Strongly Disagree

19. I believe students' use of Blackboard would reinforce self- study learning.
Strongly Agree
Agree
Neutral
Disagree
Strongly Disagree

20. I think Blackboard will promote students' use of English to communicate with peers and instructors.
Strongly Agree
Agree
Neutral
Disagree
Strongly Disagree

21. Using Blackboard would enhance working collaboratively in peers as well as in groups.
Strongly Agree
Agree
Neutral
Disagree
Strongly Disagree

22. The interface of Blackboard would draw students' attention to learn English efficiently.
Strongly Agree
Agree
Neutral
Disagree
Strongly Disagree

23. I believe learning English via Blackboard would make student feel autonomous.
Strongly Agree
Agree
Neutral
Disagree
Strongly Disagree

24. I would not recommend using Blackboard because it has several technical problems.
Strongly Agree
Agree
Neutral
Disagree
Strongly Disagree

25. I do not think that learning via Blackboard is efficient as some teachers may find it difficult to handle.
Strongly Agree
Agree
Neutral
Disagree
Strongly Disagree

Thank you.

\section{Copyrights}

Copyright for this article is retained by the author(s), with first publication rights granted to the journal.

This is an open-access article distributed under the terms and conditions of the Creative Commons Attribution license (http://creativecommons.org/licenses/by/3.0/). 